\title{
Communicational Positive Propaganda in Democracy
}

\author{
Oprea-Valentin Buşu ${ }^{1, *}$, Mirela Teodorescu ${ }^{2}$, Daniela Gîfu ${ }^{3}$ \\ ${ }^{1}$ University of Bucharest, Bulevardul Regina Elisabeta 4-12, Bucharest 030018, Romania \\ 2University of Craiova, 13 A. I. Cuza Street, Craiova, 200585, Romania \\ 3“Alexandru Ioan Cuza” University of Iaşi, Bd. Carol I no. 11, 700506, Romania \\ *E-mail address: valentino_busu@yahoo.ro
}

\begin{abstract}
This study examines the propaganda from point of view of positive effects in actual social life dominated by democracy. People have to deal with propaganda in ordinary life: it happens through advertising, propaganda occurs in political speeches, in TV shows, even in the news... With the development of means of communication and especially of mass media, propaganda has become inseparable from the contemporary mass culture. Some sociologists state that the tendencies of propagating particular lifestyles and models of behavior have a negative impact on the society; on the other hand, propaganda can be used for positive purposes: for example, for spreading healthy lifestyle, anti-smoking and anti-drugs campaigns, anti-discrimination ideas etc.
\end{abstract}

Keywords: positive propaganda; persuasive propaganda; communication

\section{INTRODUCTION}

Propaganda is defined by J. Ellul, the reputed sociologist, as a certain type of messaging that serves a particular purpose of spreading or implanting a particular culture, philosophy, point of view or even a particular slogan. Public opinion often identifies the meaning of the term "propaganda" with the negative applications of propaganda, especially the issues connected with war time and discrimination. It is not surprising because propaganda is one of the most powerful instruments in politics, and is often used to form public opinion; taking into account the frequent applications of propaganda during wartime, it is easy to understand why the common understanding of this word is linked with negative phenomena (Ellul, 1965).

Propaganda is actually a value-free term. The dictionary definition of propaganda (according to the American Heritage Dictionary) is "The systematic propagation of a doctrine or cause or of information reflecting the views and interests of those advocating such a doctrine or cause." Notice the lack of positive or negative language in that definition. Propaganda itself is not inherently negative. Certainly, it has been used for many horrific purposes throughout history. 


\section{FEATURES OF PROPAGANDA IN DEMOCRACY}

Modern propaganda exceeded tricks stage, simplistic procedures, techniques and practices, it became scientific. Despite the fact that it was not established as a discipline, propaganda was consolidated as a "technique" using "tools and techniques" of sciences such as psychology, sociology, epistemology and communication. Moreover, it improves itself with them.

In essence, propaganda is based on the psychological and sociological analyzes. It starts from the knowledge of the human being, in the specific needs, requirements, desires, tendencies, from the automatisms and mechanisms of bio-psycho-social being. It also is supported by knowledge of groups, crowds, masses, drawing in its background of laws, principles of training, dissipation and decay influence of the masses and masses capitalizing ways. All are performed by a clear consciousness of the limits imposed by the social environment (Vladutescu, 2006; Borowski, 2013; Borowski, 2014; Vlăduţescu, 2014). Propaganda is always an intentional event. Propagandistic intentionality means directed consciousness, orexic consciousness, a consciousness oriented to something. The strict and limited consciousness is an aspect of science. The paradigms of propaganda are based on nepropagandistice theories, but this can not in any way impair the the scientific nature of propaganda. As wisdom has many faces, so the propaganda has a number of forms. Wisdom is not decisively affected by cognition acquiring. Propaganda does not deathful suffer from the deficiency of theory that produces effort mobilization or moderates the propagandistic approach (J. Cazeneuve, 1976; Vladutescu, 2005; Vlăduţescu, 2013)).

We must understand, besides, that private propaganda even more than governmental propaganda, is importantly linked to democracy. Historically, from the moment a democratic regime establishes itself, propaganda establishes itself alongside it under various forms. This is inevitable, as democracy depends on public opinion and competition between political parties. In order to come to power, parties make propaganda to gain voters (Ellul, 1965).

It is evident that a conflict exists between the principles of democracy- particularly its concept of the individual and the processes of the propaganda. But this development between the democratic framework can be understood clearly if we look at it not from the level of principles but from that of actual situation. If, so far, we have concluded that inside a democracy propaganda is normal and indispensable, even intrinsic in the regime, that there are one or more propagandas at work, nothing seems to make propaganda external relations (J.-M. Domenach, 2004).

A principal aspect of propaganda is that it is subject to certain values. It is not unfettered or fettered; it is an instrument not of passion, but of reason. Therefore democratic propaganda must be essentially truthful. It must speak only the truth and base itself only on facts. The formula with which democracy explains attitude is "The truth pays". That is propaganda based on truth is more effective than any other. There is a real evolution, lies and falsifications are used less and less. The use of precise facts is becoming increasingly common (Ellul, 1965).

The democratic propagandist or democratic State will often have a bad conscience about using propaganda. The old democratic conscience still gets in the way and burdens him; he has the vague feeling that he is engaged in something illegitimate. Thus for the propagandist, in a democracy to throw himself fully into his task it is necessary that he believe, i.e. that he formulate his own convictions when he makes propaganda. Lasswell has named still another difference between democratic and totalitarian propaganda, pertaining to the technique of propaganda itself, and distinguishing between "contrasted incitement" and positive incitement". The first consist of stimulus of unleashed by the experimenter or the authorities in 
order to produce in the masses an effect in which those in power to not participate. According to Lasswell, this is a customary method of despotism. Conversely, the positive incitement, symbolizing the extended brotherly hand, is a stimulus that springs from what the powers that be really feel, in which they want to make the masses participate. It is a communal action (Lasswell, 1995).

In fact, propaganda can penetrate the consciousness of the masses of a foreign country only through the myth. It cannot operate with simple arguments pro and con. It does not address itself to already existing feelings, but must create an image to act as a motive force. This image must have an emotional character that leads to allegiance of the entire being, without thought. That is, it must be a myth. Above, we must ask ourselves what myth the democracies should use, myths of Peace, of Freedom, of Justice, and so on (Ellul, 1965).

Propaganda is a form of organized and planned persuasion to influence and direct the opinion. It is individualized in relative to context, to structuring mode, subjects at stake and the assumptions on which they build practical action. Propaganda constitutes all means, methods, procedures of producing and dissemination of messages that support and promote a doctrine, a program, a slogan or symbol belonging to a theory, a concept, an organization, aiming to persuade and win followers (Smarandache, Vlăduţescu, 2014). The term action of propaganda is that form of persuasion performed by a social operator, consisting of a deliberate influence, impositive, organized and systematic of opinions of a significant group of individuals. The concept of propaganda is subsumed to attempt of influence opinion and behavior of a target group, resulting in the adoption by the people of an opinion and a certain behavior.The influence is exerting over the masses. It occurs on topics of public opinion, using specific language and means providing a great range of penetration (theater, media, entertainment, etc.)

\section{STRUCTURE ELEMENTS OF PROPAGANDA INSTITUTION}

Institution of propaganda is delimited by three characteristics:

1. A specialized limited partner structure that is made up of management and organization centers, study, analysis, propaganda situation assessment and design centers of the actions and campaigns of propaganda (propaganda messages);

2. A derived axiology, to corresponding goals, objectives and interests of social grouping and constituting the reference values platform for designing and performing the actions, operations, propaganda campaigns;

3. A set of messages dissemination tools.

In the activity of propaganda is separated as actors: limited partners, planners and target group. The limited partners are those who feel the need to ensure a high efficiency of their social, political, economic, military carrying out, etc. They discover propaganda as mean to achieve an objective. Therefore, propaganda is not an end in itself but a mean, among others, to achieve a goal. The objective need is interpreted into the need for support. The limited partners find out that a circumstance or another need as derivatives of necessity can be satisfied by getting in the way of propaganda for a support either from the public opinion, or from some segments of the population, or from organizations or agency. The circumstances in which propaganda becomes a mean of making some interests constitute the situation of propaganda. 
Regarding the messages, topics are chosen carefully and the central ideas, to be consistent and cohesive in theme. In the project of the propaganda action integrates a feed device: a set of expected criteria of the effects, of prediction of the feed-forward effects and one of corrective control of the action according to produced effects relative to established goals and obtained feedback reactions.

Actions and campaigns of propaganda starts from the minimal idea that the first effect will be to create public opinion by means of crystallization of latent opinions, the rallying others, conformization of spread individual opinions. Propaganda uses all means of informational processing. It works seductive and mythical on the feelings, ideas, will, conscious and latent needs. Propagandistic approach suggests a global explanation of the world and it is committed in providing to target immediate reasons for acquiescence. In this direction, propaganda is continuous and hard-bitten, is of duration, is total. Propaganda is an activity of promotion and dissemination of opinions, ideas, theses, concepts and doctrines, made by a propagator of the ideology positions in order to produce training effects, modification or consolidation of opinions, attitudes or behaviors. In order to carry out the purposes and achieve goals, propaganda is focused on the subordination of public opinion, direction in which will make pressures to subordinate media (Teodorescu \& Gifu, 2014). No propaganda planner would conceive the project without taking into account the media component, by all its means.

\section{CHOMSKY \& HERMAN'S PROPAGANDA MODEL}

\section{1. General environment}

In Manufacturing Consent: The Political Economy of the Mass Media (Pantheon, 1988) Noam Chomsky and Edward Herman put forward a "propaganda model" as a framework for analyzing and understanding how the mainstream U.S. media work and why they perform as they do. The authors asserts that they had long been impressed with the regularity with which the media operate within restricted assumptions, depend heavily and uncritically on elite information sources, and participate in propaganda campaigns helpful to elite interests.

In trying to explain why they do this, the authors, looked for structural factors as the only possible root of systematic behavior and performance patterns. As Chomsky \& Herman assert, "the propaganda model was and is in distinct contrast to the prevailing mainstream explanations -- both liberal and conservative -- of media behavior and performance. These approaches downplay structural factors, generally presupposing their unimportance or positive impact because of the multiplicity of agents and thus competition and diversity. Liberal and conservative analysts emphasize journalistic conduct, public opinion, and news source initiatives as the main determining variables. The analysts are inconsistent in this regard, however. When they discuss media systems in communist or other authoritarian states, the idea that journalists or public opinion can override the power of those who own and control the media is dismissed as nonsense and even considered an apology for tyranny".

Because of the goals, there is a distinct difference, between the political implications of the propaganda model and mainstream scholarship. The authors explains that, a basic change in media ownership, organization, and purpose is necessary for the achievement of genuine democracy, if structural factors shape the broad contours of media performance, and if that performance is incompatible with a truly democratic political culture. Also, in mainstream analyses such a perspective is politically unacceptable, and its supportive arguments and evidence are rarely subject to debate (Chomsky and Herman, 1988). 


\section{2. The propaganda model}

Chomsky \& Herman show in their study the mechanisms of propaganda model. So, "the crucial structural factors derive from the fact that the dominant media are firmly imbedded in the market system. They are profit-seeking businesses, owned by very wealthy people (or other companies); they are funded largely by advertisers who are also profit-seeking entities, and who want their ads to appear in a supportive selling environment. The media are also dependent on government and major business firms as information sources, and both efficiency and political considerations, and frequently overlapping interests, cause a certain degree of solidarity to prevail among the government, major media, and other corporate businesses. Government and large non-media business firms are also best positioned (and sufficiently wealthy) to be able to pressure the media with threats of withdrawal of advertising or TV licenses, libel suits, and other direct and indirect modes of attack. The media are also constrained by the dominant ideology, which heavily featured anticommunism before and during the Cold War era, and was mobilized often to prevent the media from criticizing attacks on small states labeled communist" (Chomsky \& Herman, 1988).

The authors make obvious their statements by examples. Propaganda campaigns can occur only when consistent with the interests of those controlling and managing the filters. For example, these managers all accepted the view that the Polish government's crackdown on the Solidarity union in 1980-81 was extremely newsworthy and deserved severe condemnation; whereas the same interests did not find the Turkish military government's equally brutal crackdown on trade unions in Turkey at about the same time to be newsworthy or reprehensible. In the latter case the U.S. government and business community liked the military government's anticommunist stance and open door economic policy; and the crackdown on Turkish unions had the merit of weakening the Left and keeping wages down. In the Polish case, propaganda points could be scored against a Soviet-supported government, and concern could be expressed for workers whose wages were not paid by Free World employers! The fit of this dichotomization to corporate interests and anticommunist ideology is obvious.

The concepts of "worthy" and "unworthy" victims, asserts the authors, to describe this dichotomization, with a trace of irony, as the differential treatment was clearly related to political and economic advantage rather than anything like actual worth. In fact, the Polish trade unionists quickly ceased to be worthy when communism was overthrown and the workers were struggling against a western-oriented neoliberal regime. The travails of Polish workers now, like those of Turkish workers, do not pass through the propaganda model filters. They are both unworthy victims at this point.

Also, the authors declare that they never claimed that the propaganda model explains everything or that it shows media omnipotence and complete effectiveness in manufacturing consent. It is a model of media behavior and performance, not media effects. "We explicitly pointed to alternative media, grass roots information sources, and public skepticism about media veracity as important limits on media effectiveness in propaganda service, and we urged the support and more effective use of these alternatives. We have frequently pointed to the general public's disagreement with the media and elite over the morality of the Vietnam War and the desirability of the assault on Nicaragua in the 1980s (among other matters). The power of the U.S. propaganda system lies in its ability to mobilize an elite consensus, to give the appearance of democratic consent, and to create enough confusion, misunderstanding, and apathy in the general population to allow elite programs to go forward. We also emphasized the fact that there are often differences within the elite that open up space for some debate and even occasional (but very rare) attacks on the intent, as well as the tactical means of achieving elite ends". 
The model does suggest that the mainstream media, as elite institutions, commonly frame news and allow debate only within the parameters of elite interests; and that where the elite is really concerned and unified, and/or where ordinary citizens are not aware of their own stake in an issue or are immobilized by effective propaganda, the media will serve elite interests uncompromisingly (Chomsky \& Herman, 1988).

But professionalism and objectivity rules are fuzzy, flexible, and superficial manifestations of deeper power and control relationships. Professionalism arose in journalism in the years when the newspaper business was becoming less competitive and more dependent on advertising. Professionalism was not an antagonistic movement by the workers against the press owners, but was actively encouraged by many of the latter. It gave a badge of legitimacy to journalism, ostensibly assuring readers that the news would not be influenced by the biases of owners, advertisers, or the journalists themselves. In certain circumstances it has provided a degree of autonomy, but professionalism has also internalized some of the commercial values that media owners hold most dear, like relying on inexpensive official sources as the credible news source.

This can be assimilated also to neutrosophy concept, according which this kind of situation is between true and false, between right and wrong. "Communicational relations always comprise a set of neutral, neutrosophic meanings. Communication in general is a human manifestation of life with recognizable profile. Particularly, we talk about scientific communication, literary communication, pictorial communication, sculptural communication, esthetic communication and so on, as specific manifestations of life. All these include coherent, cohesive and structural series of existential meanings which are contradictory and/or neutral, neutrosophic. It can be asserted that in any communication there are routes of access and neutrosophic routes. Any communication is traversed by neutrosophic routes of communication" (Vladutescu \& Smarandache, 2014).

The propaganda model is dealing with extraordinarily complex sets of events, and only claims to offer a broad framework of analysis that requires modification depending on many local and special factors, and may be entirely inapplicable in some cases. But if it offers insight in numerous important cases that have large effects and cumulative ideological force, it is defensible unless a better model is provided. Usually the critics wisely stick to generalities and offer no critical detail or alternative model; when they do provide alternatives, the results are not impressive.

\section{3. Filters - enhanced relevance of the propaganda model}

The dramatic changes in the economy, communications industries, and politics over the past decade have tended to enhance the applicability of the propaganda model. Chomsky and Herman set five types of filters of the Propaganda Model: ownership, advertising, sourcing, flak and anticommunist ideology.

The first two filters -- ownership and advertising -- have become ever more important. The decline of public broadcasting, the increase in corporate power and global reach, and the mergers and centralization of the media, have made bottom line considerations more controlling. The competition for serving advertisers has become more intense. Newsrooms have been more thoroughly incorporated into transnational corporate empires, with shrunken resources and even less management enthusiasm for investigative journalism that would challenge the structure of power.

In short, the professional autonomy of journalists has been reduced. Some argue that the Internet and the new communication technologies are breaking the corporate stranglehold on journalism and opening an unprecedented era of interactive democratic media. There is no 
evidence to support this view as regards journalism and mass communication. In fact, one could argue that the new technologies are exacerbating the problem.

They permit media firms to shrink staff while achieving greater outputs and they make possible global distribution systems, thus reducing the number of media entities. Although the new technologies have great potential for democratic communication, left to the market there is little reason to expect the Internet to serve democratic ends (Chomsky \& Herman, 1988).

The third and fourth filters -- sourcing and flak -- have also strengthened as mechanisms of elite influence. A reduction in the resources devoted to journalism means that those who subsidize the media by providing sources for copy gain greater leverage (Chomsky and Herman, 1988).

The fifth filter -- anticommunist ideology -- is possibly weakened by the collapse of the Soviet Union and global socialism, but this is easily offset by the greater ideological force of the belief in the "miracle of the market." (Reagan) There is now an almost religious faith in the market, at least among the elite, so that regardless of evidence, markets are assumed benevolent and non-market mechanisms are suspect.

When the Soviet economy stagnated in the 1980s, it was attributed to the absence of markets; when capitalist Russia disintegrated in the 1990s it was because politicians and workers were not letting markets work their magic. Journalism has internalized this ideology. Adding it to the fifth filter, in a world where the global power of market institutions makes anything other than market options seem utopian, gives us an ideological package of immense strength (Chomsky and Herman, 1988).

\section{EXAMPLES OF POSITIVE PROPAGANDA}

\section{1. Drug war campaign}

In late 1960s recreational drug use becomes fashionable among young, white, middle class Americans. The social stigmatization previously associated with drugs lessens as their use becomes more mainstream.

Drug use becomes representative of protest and social rebellion in the era's atmosphere of political unrest. In this context started the fight against drugs both in USA administration by law enforcement, and in drugs producers country supporting the governments. Year by year the propaganda campaigns progressed by all means. One of slogans launched in campaign by First Lady Nancy Reagan was "Just say no". (World Health Organization - Archive and Statisyical Data; United Nations - Archive and Statistical Data).

\section{2. Green peace campaigns}

October 2009: Apple clears the last hurdle to removing toxic PVC plastic in its new Macbook and iMac, capping the "Green my Apple" campaign with a win and making Apple products safer, easier to recycle and causing less pollution at the end of their life.

September 2010: Over one million signatures calling for a moratorium on genetically modified (GM) crops were delivered by Avaaz and Greenpeace to John Dalli, Commissioner of Health and Consumer Policy, at the EU Commission in Brussels. The signatures were printed on the world's largest piece of art made by one man - a 3D hand painted scene of an organic farm with agricultural biodiversity that is GM-free. It represents the way most Europeans want their food and fields. 
September 2011: It took seven years, teams of young campaigners and hordes of devoted supporters, but the Chinese government finally said it was suspending the commercialization of genetically-engineered (GE) rice.

May 2012: For over a year, Greenpeace campaigned intensively for the cancellation of Senegalese fishing authorizations. These licenses constituted a serious threat to the livelihoods of millions of Senegalese who depend on the ocean's resources for their jobs and food security. Organizing a travelling caravan called "My voice, my future," that engaged artisanal fishermen across the country, launching an online petition, meeting with politicians, and organizing a ship tour to expose and document overfishing in Senegalese waters, were some of the actions Greenpeace took to achieve this result. So it was with joy that we learned of the Senegalese government's decision to cancel the fishing authorizations issued to 29 foreign pelagic trawlers in West African waters.

December 2012: Brazilian oil giant Petrobras has abandoned its plans for deep sea oil drilling off the coast of New Zealand. The world's third largest oil company has decided to return its exploration licenses for deep sea oil and gas prospects to the government, effectively abandoning its plans for deep sea drilling in New Zealand.

March 2013: VW have caved in to pressure from across the globe and announced they will meet and support climate targets. VW has now publicly agreed to live up to its promises to be the world's greenest car company, setting an example for the rest of the industry.

January 2014: British luxury brand Burberry made a commitment to eliminate the use of hazardous chemicals from its supply chain by 1 January 2020. Burberry's move comes after just two weeks of people-powered campaigning on the brand's social media channels, reaching an audience of millions, while Greenpeace volunteers held protests at stores from Beijing to Mexico City. Burberry joins 18 big brands like Zara, Valentino and H\&M who have committed to Detox their clothes and manufacturing processes

Data supplied by Greenpeace Organization.

\section{3. Reducing poverty, promoting prosperity and protecting the planet}

United Nations developed efforts profoundly affecting the lives and well-being of millions of people throughout the world. They are based on the conviction, persuasion propaganda that lasting international peace and security are possible only if the economic prosperity and the well-being of people everywhere is assured.

These are only few examples of thousands projects that are on going to refresh and influence our mental regarding conditions of social life on this planet.

It is important to note that to have a lasting effect, propaganda needs in this or that way to have an influence on the system of education. One of the most effective means of propaganda is misinformation in historical context: people do not have a lot of possibilities to check the accuracy of the information, historical events etc.; in addition to that, historians often analyze the events including (or even using) their point of view; this also gives various space for propaganda. As usual, facts provided at school are not checked by people when they grow older; this is why different facts or opinions that never existed start becoming "common knowledge" (Howe, 1982). 


\section{CONCLUSIONS}

It should be noted that in the current conditions of democracy, access to information, diversity of communication methods, the propagandistic persuasion strategy is developed benefiting of propagandist 's propensity, talent, prestige, by seduction determined by meticulous and neutrosophical statements, based on myths presented by natural reasoning, through the perseverance of argumentation, the influence the mind. Thus we can achieve outstanding results to influence in a good way, results that lead us to a comprehensive understanding of the idea, concept, theme, purposed propaganda launched by the propagandistic action.

\section{ACKNOWLEDGMENT}

This work was partially supported by the grant number $33 \mathrm{C} / 2014$, awarded in the internal grant competition of the University of Craiova.

\section{References}

[1] N. Chomsky, George A. Miller (1962). Introduction to the Formal Analysis of Natural Languages. In R. R. Bush, E. Galanter, R. D. Luce. Handbook of Mathematical Psychology 2. Wiley. pp. 269-321.

[2] Jason L. Powell, International Letters of Social and Humanistic Sciences 17(1) (2014) $1-60$.

[3] Ioan Constantin Dima, Ştefan Vlăduţescu (2012). Persuasion elements used in logistical negotiation: Persuasive logistical negotiation. Saarbrucken: LAP Lambert Academic Publishing.

[4] Andrzej Borowski, International Letters of Social and Humanistic Sciences 14 (2014) 7-17.

[5] M. Milca (2001). Geneza teoriei elitelor. Provocarea neomachiavellienilor. Bucureşti: Editura Economică.

[6] Virgil Măgureanu (2003). Declinul sau apoteoza puterii? Rao.

[7] Andrzej Borowski, International Letters of Social and Humanistic Sciences 4 (2013) $70-74$.

[8] Mirela Teodorescu, Alina Tenescu, Communications in Applied Sciences 2(1) (2014).

[9] Ştefan Vlăduţescu (2013). What Kind of Communication Is Philosophy. Jokull.

[10] Mirela Teodorescu, Daniela Gîfu, International Letters of Social and Humanistic Sciences 17 (2014) 119-127.

[11] Andrezj Borowski, International Letters of Social and Humanistic Sciences 2 (2014) 110-121.

[12] Florentin Smarandache, Ştefan Vlăduţescu (2014). Neutrosophic Emergences and Incidences in Communication and Information. Saarbrucken: LAP Lambert Academic Publishing. 
[13] Mirela Teodorescu, Ioan Constantin Dima, Daniela Gifu, International Letters of Social and Humanistic Sciences 20 (2014) 46-55

[14] Andrezj Borowski, International Letters of Social and Humanistic Sciences 3 (2013) 69-74.

[15] Ş. Vlăduţescu, E. M. Ciupercă (2013). Next Flood Level of Communication: Social Networks. Aachen: Shaker Verlag.

[16] Mirela Teodorescu, Daniela Gîfu, International Letters of Social and Humanistic Sciences 18 (2014) 48-57.

[17] A. Borowski, International Letters of Social and Humanistic Sciences 11 (2014) 1-168.

[18] Ștefan Vlăduțescu (2013). Principle of the Irrepressible Emergence of the Message. Jokull.

[19] Tomáš Hes, Anna Poledňáková, International Letters of Social and Humanistic Sciences 2 (2013) 18-31.

[20] Andrzej Borowski, International Letters of Social and Humanistic Sciences 3 (2013) 46-53.

[21] Kinga Dziwańska, International Letters of Social and Humanistic Sciences 7 (2013) 96-112.

[22] Ștefan Vlăduțescu, International Letters of Social and Humanistic Sciences 10 (2014) 100-106.

[23] Andrzej Borowski, International Letters of Social and Humanistic Sciences 14 (2014) $33-41$.

[24] Jacques Ellul (1965). Propaganda: The Formation of Men's Attitudes. Paris.

[25] Ștefan Vlăduțescu, International Letters of Social and Humanistic Sciences 7 (2014) $8-13$.

[26] M. Colhon (2013). Automatic Lexical Alignment between Syntactically Weak Related Languages. Application for English and Romanian. In Computational Collective Intelligence. Technologies and Applications (pp. 266-275). Springer Berlin Heidelberg.

[27] Janusz Grabara, Michal Kolcun, Sebastian Kot, International Journal of Education and Research 2(2) (2014).

[28] Ștefan Vlăduțescu, International Letters of Social and Humanistic Sciences 24 (2014) 86-94.

[29] Sebastian Kot, Janusz Grabara, Michal Kolcun, International Letters of Social and Humanistic Sciences 15 (2014) 1-6.

[30] Ştefan Vlăduţescu, Journal of Studies in Social Sciences 8(2) (2014).

[31] J. H. Gasderell, International Letters of Social and Humanistic Science 22 (2014) 85-91.

[32] J. Bushati, A. Tana, G. Dibra, E. Lezha, European Scientific Journal 10(13) (2014).

[33] V. A. Enăchescu, C. Damasaru, Revista de Management Comparat Internaţional/ Review of International Comparative Management 14(4) (2013) 644-653.

[34] Agnieszka Ulfik, Stefan Nowak, Polish Journal of Environmental Studies 23(3) (2014). 
[35] Vlad Roşca, Theoretical and Applied Economics, 1(1) (2012) 127.

[36] Sebastian Kot, Beata Ślusarczyk, The Journal of American Business Review Cambridge (2014).

[37] G. Rajović, J. Bulatović, International Letters of Natural Sciences 1 (2014) 33-53.

[38] Ștefan Vlăduțescu, International Letters of Social and Humanistic Sciences 15(2) (2014) 164-170.

[39] Tomáš Hes, Alena Neradová, Karel Srnec, International Letters of Social and Humanistic Sciences 7 (2013) 55-75.

[40] Ș. Vlăduțescu (2006). Comunicare jurnalistică negativă. Bucureşti: Editura Academiei.

[41] Mirela Teodorescu, Vladimir Modrak, Daniela Gîfu, International Letters of Social and Humanistic Sciences 24 (2014) 56-65.

[42] Rodica Pascu (2007). Comunicare interculturală. Sibiu.

[43] Max G. Craig, Journal of Studies in Social Sciences 8(1) (2014).

[44] Aurelia Traistaru, (2013). Consolidation of the green marketing profile in current austerity period. Jokull.

[45] Ştefan Vlăduţescu, European Scientific Journal 9(32) (2013).

[46] J.-M. Domenach (2004). Propaganda politică. Iaşi: Editura Institutul European.

[47] H. D. Lasswell (1995). Propaganda (Main Trends of the Modern World). Houndmills, Basingstoke: Macmillans

[48] Andrzej Borowski International Letters of Social and Humanistic Sciences 7 (2013) 113-118.

[49] Andrzej Borowski, International Letters of Social and Humanistic Sciences 11 (2013) 100-105.

[50] Okezie A. Ihugba, Alex Odii, A. C. Njoku, International Letters of Social and Humanistic Sciences 5 (2014) 21-34.

[51] J. Cazeneuve (1976). La Communication de Masse. Guide alphabétique. Paris: DenoëlGonthier.

[52] Vlăduţescu Şt. (2004). Hipoacuzia şi surditatea ca boli profesionale. Sitech Publishing House, Craiova.

[53] A. M. Târnovan (2010). Transcultural Values and Meanings in International Marketing and Advertising. In 17th International Economic Conference-IECS, Sibiu, The Economic World Destiny: Crisis and Globalization, Sibiu, Romania.

[54] J. Shopovski, F. Bezzina, M. M. Zammit, European Scientific Journal 9(7) (2013).

[55] Florentin Smarandache, Ştefan Vlăduţescu (2014). Communication Neutrosophic Routes. Columbus, OH: Educational Publishing.

[56] Mirela Teodorescu, Daniela Gîfu, Dan Ionescu, International Letters of Social and Humanistic Sciences 17 (2014) 61-69.

[57] M. Teodorescu, International Letters of Social and Humanistic Sciences 15 (2014) 53-62. 
[58] Jovan Shopovski, (2012). Legal framework concerning gender equality in Republic of Macedonia. In Book of Proceedings (p. 324).

[59] Mirela Teodorescu, Petre Bosun, Daniela Gîfu, International Journal of Education and Research 2(3) (2014).

[60] Mădălina Cerban (2013). Rehabilitation of the Mother Tongue in Teaching EFL to Adult Learners. Procedia-Social and Behavioral Sciences.

[61] Mirela Teodorescu, Dan Ionescu, International Letters of Social and Humanistic Sciences 14 (2014) 50-58.

[62] Jason L. Powell, International Letters of Social and Humanistic Sciences 16(2) (2014) 177-183. 